Research Article

\title{
Calorimetric Study of Helix aspersa Maxima Hemocyanin Isoforms
}

\author{
Svetla Todinova $\mathbb{D}^{1},{ }^{1}$ Yuliana Raynova, ${ }^{2}$ and Krassimira Idakieva ${ }^{2}$ \\ ${ }^{1}$ Institute of Biophysics and Biomedical Engineering, Bulgarian Academy of Sciences, Bl. 21, Acad. G. Bonchev Str., Sofia 1113, Bulgaria \\ ${ }^{2}$ Institute of Organic Chemistry with Centre of Phytochemistry, Bulgarian Academy of Sciences, Bl. 9, Acad. G. Bonchev Str., \\ Sofia 1113, Bulgaria
}

Correspondence should be addressed to Svetla Todinova; todinova@abv.bg

Received 29 September 2017; Accepted 31 December 2017; Published 4 March 2018

Academic Editor: Ricardo Jorgensen Cassella

Copyright (c) 2018 Svetla Todinova et al. This is an open access article distributed under the Creative Commons Attribution License, which permits unrestricted use, distribution, and reproduction in any medium, provided the original work is properly cited.

\begin{abstract}
The thermal unfolding of hemocyanin isoforms, $\beta-\mathrm{HaH}$ and $\alpha_{D+N}-\mathrm{HaH}$, isolated from the hemolymph of garden snails Helix aspersa maxima, was studied by means of differential scanning calorimetry (DSC). One transition, with an apparent transition temperature $\left(T_{m}\right)$ at $79.88^{\circ} \mathrm{C}$, was detected in the thermogram of $\beta$ - $\mathrm{HaH}$ in $20 \mathrm{mM}$ HEPES buffer, containing $0.1 \mathrm{M} \mathrm{NaCl}, 5 \mathrm{mM}$ $\mathrm{CaCl}_{2}$, and $5 \mathrm{mM} \mathrm{MgCl}_{2}, \mathrm{pH} 7.0$, at scan rate of $1.0^{\circ} \mathrm{Cmin}^{-1}$. By means of successive annealing procedure, two individual transitions were identified in the thermogram of $\alpha_{D+N}-\mathrm{HaH}$. Denaturation of both hemocyanins was found to be an irreversible process. The scan-rate dependence of the calorimetric profiles indicated that the thermal unfolding of investigated hemocyanins was kinetically controlled. The thermal denaturation of the isoforms $\beta$-HaH and $\alpha_{D+N}-\mathrm{HaH}$ was described by the two-state irreversible model, and parameters of the Arrhenius equation were calculated.
\end{abstract}

\section{Introduction}

Many natural proteins act as a functional basis of biologic drugs [1]. One of the first steps, required to outline the design of the therapeutic properties of protein drugs, is their thermodynamic characterization [2]. The attainment of desired thermodynamic features of proteins is a relatively new area in biotechnology. Thus, protein stabilization becomes a main goal in medicine and scientific research. The mechanism of folding and unfolding gives knowledge on the function and the possibilities of protein stabilization. Differential scanning calorimetry (DSC) is the most useful technique for analyzing the protein thermal stability. This method measures the heat capacity change, associated with protein thermal denaturation, as a function of temperature. The integral of the excess heat capacity function is the enthalpy in this process. Thermodynamic parameters, such as temperature of unfolding $\left(T_{m}\right)$ and change in enthalpy, give huge information about the structure and functional parameters of the proteins, as well as about the nature of their interactions with other ligands or drug [3-5].
Hemocyanins (Hcs) are oligomeric copper-containing glycoproteins that function as oxygen carriers in the hemolymph of several molluscs and arthropods [6, 7]. Besides their important biological function, a variety of medical applications of molluscan Hcs emerged. Recently, we have established that the Hcs of marine mollusk Rapana thomasiana ( $\mathrm{RtH})$ and $\beta$-Hc isoform of $\mathrm{H}$. pomatia $(\beta-\mathrm{HpH})$ are suitable as potential bioadjuvants for subunit vaccines and that these Hcs could be used as natural adjuvants or protein carriers $[8,9]$. The anticancer properties of both molluscan Hcs have been demonstrated on a murine model of colorectal cancer in vivo [10]. A number of DSC studies have shown that Hcs possess considerable thermal stability. Melting temperature $\left(T_{m}\right)$ in the range $83-90^{\circ} \mathrm{C}$ was observed for the RtH [11], $\beta-\mathrm{HpH}$ [12], and the Hc of marine gastropod Concholepas concholepas (CCH) [13]. Calorimetric studies demonstrate also the high thermostability of Hcs from arthropods, for example, Hcs of tarantula Eurypelma californicum $\left(T_{m} 90^{\circ} \mathrm{C}\right)[14]$ and of horseshoe crab Limulus polyphemus $\left(T_{m} 92^{\circ} \mathrm{C}\right)$ [15]. It is considered that the interactions between subunits and the high degree of 
oligomerization stabilize the quaternary structure of the $\mathrm{Hc}$ molecules $[15,16]$.

In certain species of mollusc, an expression of functionally distinct $\mathrm{Hc}$ isoforms has been observed [17]. The physiological relevance of these isoforms is still not clear, but its expression may be connected to the development of species [18]. Heterogeneity at a molecular level has been described first for the Hc from Helix species [19]. Three types of Hc molecules or isoforms have been identified in the hemolymph isolated from the Roman snail Helix pomatia: $\beta$-Hc, $\alpha_{D}$-Hc (dissociating $\alpha-\mathrm{Hc}$ ), and $\alpha_{N^{-}} \mathrm{Hc}$ (nondissociating $\alpha-\mathrm{Hc})[6,20]$. The isoform $\beta-\mathrm{HpH}$ consists of only one type of polypeptide chain ( $\beta$ subunits) compared with two types ( $\alpha$ and $\alpha^{\prime}$ subunits) in each of both $\alpha$-Hcs [20]. Due to the subunit homogeneity, structural and immunological investigations have been performed primarily on $\beta$-HpH. Gielens et al. have identified three types of $\mathrm{Hc}$ components in the hemolymph of garden snails Helix aspersa [21]. Three isoforms $\left(\beta-\mathrm{HlH}, \alpha_{N^{-}} \mathrm{HlH}\right.$, and $\left.\alpha_{D^{-}} \mathrm{HlH}\right)$ have been reported also for the garden snail Helix lucorum [22]. Recently, the Hc of snails Helix aspersa maxima $(\mathrm{HaH})$ was isolated and characterized [23, 24]. On the basis of the o-diphenoloxidase activity of $\mathrm{HaH}$, a model of biosensor for quantitative determination of phenols in aqueous solutions was developed [23]. Moreover, this Hc can be produced in large quantities for biotechnology and medical use from snails, bred in special farms under controlled conditions; therefore, the knowledge of its thermal stability is essential.

In the present study, for the first time, the thermal stability of the individual $H$. aspersa maxima $\mathrm{Hc}$ isoforms has been characterized by means of DSC. The data are compared with those obtained for other molluscan Hcs in order to acquire further insight into the structural stability of the oxygen-transport proteins from invertebrates.

\section{Materials and Methods}

2.1. Hemocyanin Preparation. Native $\mathrm{HaH}$ was isolated in compliance with the procedure described in [23]. Briefly, the Hc was obtained from the hemolymph, collected from snails Helix aspersa maxima, by ultracentrifugation at $180000 \times \mathrm{g}$ (ultracentrifuge Beckman LM-80, rotor Ti 45), for 4 hours, at $4^{\circ} \mathrm{C}$. The pellets were resuspended in $50 \mathrm{mM}$ phosphate buffer, $\mathrm{pH} 7.2$, and $\mathrm{HaH}$ was further purified by gel filtration chromatography on a Sepharose $4 \mathrm{~B}$ column $(90 \times 2.4 \mathrm{~cm})$. Further, $\mathrm{HaH}$ was separated into its isoforms $(\beta-\mathrm{HaH}$ and $\left.\alpha_{D+N}-\mathrm{HaH}\right)$ by ion exchange chromatography on a DEAESepharose CL-6B column $(32 \times 1.2 \mathrm{~cm})$ and equilibrated and eluted with buffer $50 \mathrm{mM}$ Tris- $\mathrm{HCl}, \mathrm{pH}$ 8.0, using a linear gradient $0.1-0.45 \mathrm{M} \mathrm{NaCl}$. Specific absorption coefficient $a_{278} \mathrm{~nm}=1.413 \mathrm{ml} \cdot \mathrm{mg}^{-1} \cdot \mathrm{cm}^{-1}$ for $\mathrm{HaH}$ [21] was used for determination of the protein concentration.

2.2. Differential Scanning Calorimetry. Calorimetric measurements were performed using high-sensitivity differential adiabatic scanning microcalorimeter DASM-4 (Biopribor, Pushchino, Russia), with a sensitivity $>0.017 \mathrm{~mJ} \cdot \mathrm{K}^{-1}$ and a noise level $< \pm 0.05 \mu \mathrm{W}$. Four different scan rates $(0.2,0.5$, 1.0 , and $1.5^{\circ} \mathrm{C} \mathrm{min}{ }^{-1}$ ) were used. The reversibility of the thermal transitions was checked by examining the reproducibility of the calorimetric trace in a subsequent heating of the sample immediately after cooling following the first scan. In all cases, the thermal denaturation was found to be irreversible; therefore, the thermogram corresponding to the reheating run was used as an instrumental baseline. The transitions were corrected with regard to the difference in heat capacity between the initial and final state by using a linear chemical baseline. The molar excess heat capacity curves, obtained by normalizing with the protein concentrations and the known volume of the calorimetric cell, were smoothed and plotted using the Windows-based software package (Origin). The temperature at the maximum of the excess heat capacity curve was taken as the transition temperature $\left(T_{m}\right)$. DSC measurements were carried out in buffer $20 \mathrm{mM}$ HEPES, containing $100 \mathrm{mM} \mathrm{NaCl}, 5 \mathrm{mM}$ $\mathrm{CaCl}_{2}$, and $5 \mathrm{mM} \mathrm{MgCl}_{2}, \mathrm{pH} 7.9\left(20^{\circ} \mathrm{C}\right)$. The temperature coefficient of HEPES buffer is $-0.014 \Delta \mathrm{pK}^{\circ} \mathrm{C}^{-1}$.

2.3. Data Analysis. The DSC data were analyzed by means of the nonlinear least-squares method using the Origin 8 software package (Origin Lab Corp.). In all fitting procedures, the correlation coefficient $r$, used as a criterion for the accuracy of fitting, was not less than 0.99. In the calculation of molar quantities, the molecular mass used for the protein was $9000 \mathrm{kDa}$.

DSC transitions were analyzed in terms of the two-state kinetic model:

$$
N \stackrel{k}{\rightarrow} D
$$

which is a limiting case of the Lumry-Eyring model [25]. This model considered only two significantly populated macroscopic states: the initial or native state $(N)$, and the final or denatured state $(D)$, the transition between which is determined by a strongly temperature-dependent first-order rate constant $(k)$. The Arrhenius equation represents the temperature dependence of $k$ :

$$
k=\exp \left[\frac{E_{a}}{R}\left(\frac{1}{T^{*}}-\frac{1}{T}\right)\right],
$$

where $E_{a}$ is the activation energy of the denaturation process, $R$ is the gas constant, and $T^{*}$ is the temperature at which $k$ is equal to $1 \mathrm{~min}^{-1}$.

In this case, the excess heat capacity $C_{p}^{e x}$ is given by the following equation [26]:

$$
\begin{aligned}
C_{p}^{\mathrm{ex}}= & \frac{1}{v} \Delta H \exp \left\{\frac{E_{a}}{R}\left(\frac{1}{T^{*}}-\frac{1}{T}\right)\right\} \\
& \times \exp \left\{-\frac{1}{v} \int_{T_{0}}^{T} \exp \left[\frac{E_{a}}{R}\left(\frac{1}{T^{*}}-\frac{1}{T}\right) \mathrm{d} T\right]\right\},
\end{aligned}
$$

where $v=\mathrm{d} T / \mathrm{d} t\left(\mathrm{~K} \mathrm{~min}^{-1}\right)$ is a scan rate value and $\Delta H$ is the enthalpy difference between the denatured and native states.

\section{Results and Discussion}

3.1. DSC of Purified HaH Isoforms. The three Hc isoforms $\left(\beta-\mathrm{HaH}, \alpha_{D}-\mathrm{HaH}\right.$, and $\left.\alpha_{N}-\mathrm{HaH}\right)$, identified in the hemolymph 


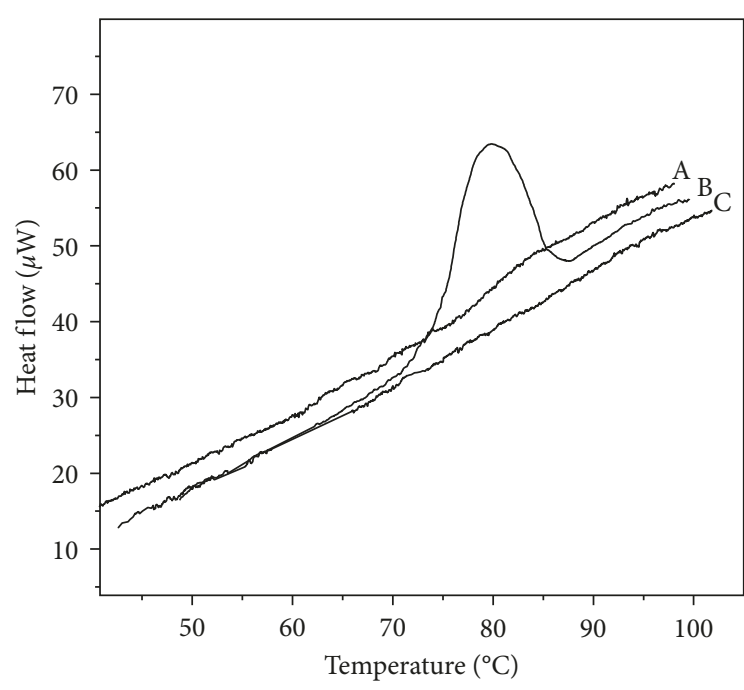

(a)

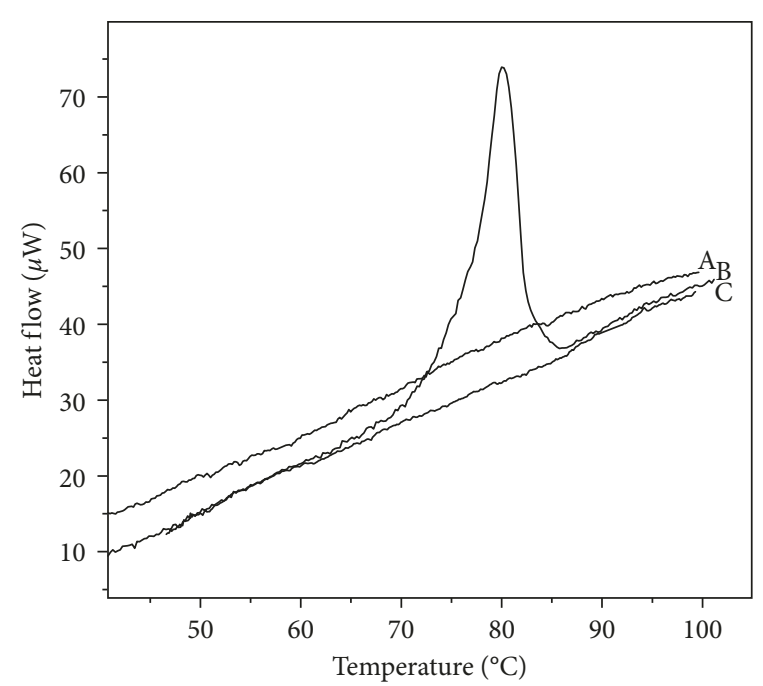

(b)

FiguRE 1: Original calorimetric recording of the apparent heat capacity of isoforms $\beta-\mathrm{HaH}$ (a) and $\alpha_{D+N}-\mathrm{HaH}$ (b) as a function of the temperature (line B); reheating scan (line C); and baseline obtained with buffer in both cells of the calorimeter (line A). The experimental curves shown refer to $\beta-\mathrm{HaH}\left(2.88 \mathrm{mg} \cdot \mathrm{ml}^{-1}\right)$ and $\alpha_{D+N^{-}} \mathrm{HaH}\left(3 \mathrm{mg} \cdot \mathrm{ml}^{-1}\right)$ in buffer $20 \mathrm{mM} \mathrm{HEPES}$, containing $100 \mathrm{mM} \mathrm{NaCl}, 5 \mathrm{mM} \mathrm{CaCl}{ }_{2}$, and $5 \mathrm{mM} \mathrm{MgCl} 2\left(\mathrm{pH} 7.06\right.$ at $\left.80^{\circ} \mathrm{C}\right)$, at scan rate of $1.0^{\circ} \mathrm{C} \mathrm{min}^{-1}$.

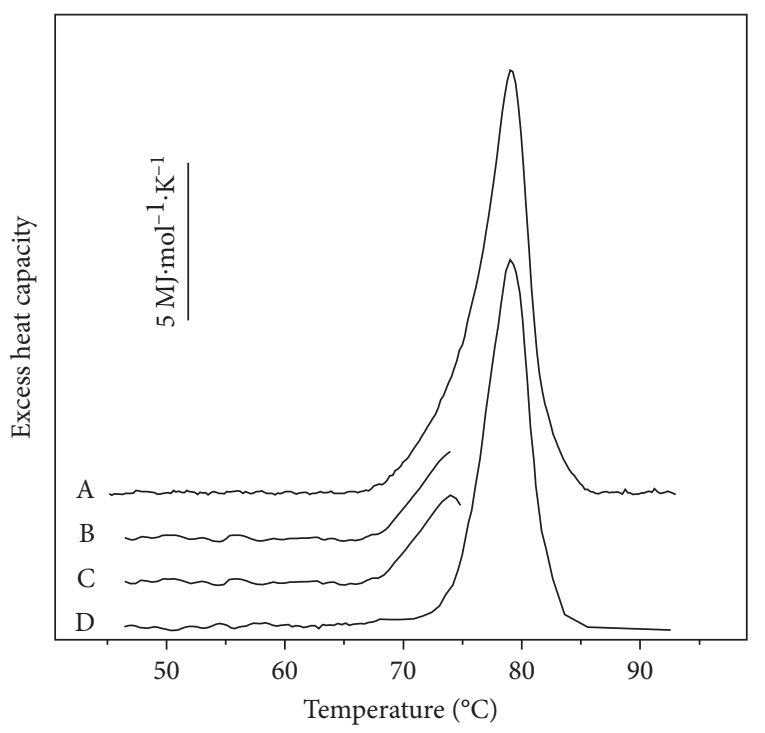

(a)

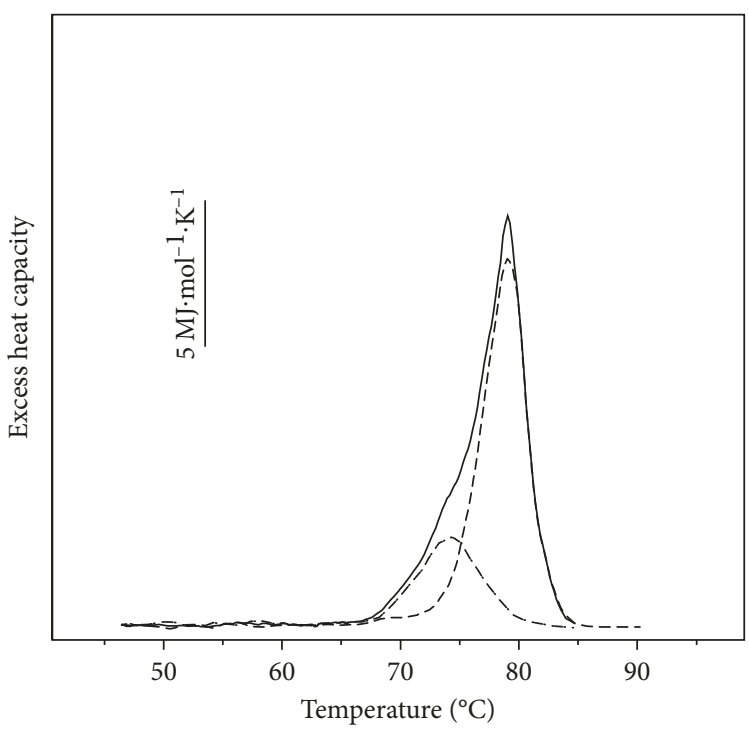

(b)

Figure 2: Example of the successive annealing process. (a) Complete calorimetric scan of $\alpha_{D+N^{-}} \mathrm{HaH}$ in buffer $20 \mathrm{mM}$ HEPES (pH 7.06 at $80^{\circ} \mathrm{C}$ ), at scan rate of $0.5^{\circ} \mathrm{C} \mathrm{min}{ }^{-1}$ (line A); the first scan of a new sample with the same composition, stopped at $74.5^{\circ} \mathrm{C}$ (line $\mathrm{B}$ ); result of subtracting the following (second scan) DSC line from the first one (line C); and the second calorimetric scan stopped at $90^{\circ} \mathrm{C}$ (line D). (b) Result of the deconvolution of the experimental contour (solid line), which provides two individual components (dash lines).

of snails $H$. aspersa maxima, were isolated by ion exchange chromatography. The isoform $\beta$-HaH (pI 5.2) eluted as a single symmetric peak, followed by a peak containing both electrophoretically similar $\alpha$-isoforms (pI 4.6), which eluted together as $\alpha_{D+N^{-}} \mathrm{HaH}$, as previously described by Raynova and coworkers [23]. At neutral $\mathrm{pH}$ and in the presence of $\mathrm{Ca}^{2+}$ and $\mathrm{Mg}^{2+}$, these Hc molecules occur as a didecamers of $\sim 450 \mathrm{kDa}$ subunits.

The thermogram of the isoform $\beta-\mathrm{HaH}$ in buffer $20 \mathrm{mM}$ HEPES, pH 7.0, containing $100 \mathrm{mM} \mathrm{NaCl}, 5 \mathrm{mM} \mathrm{CaCl}_{2}$, and $5 \mathrm{mM} \mathrm{MgCl}_{2}$, at a heating rate of $1.0^{\circ} \mathrm{C} \mathrm{min}^{-1}$, is shown in Figure 1(a) (line B). Heat absorption was observed between 70 and $87^{\circ} \mathrm{C}$, with an apparent transition temperature $\left(T_{m}\right)$ at $79.88^{\circ} \mathrm{C}$. Value of $145.0 \mathrm{MJ} \mathrm{mol}^{-1}$ was calculated for the calorimetric enthalpy $\left(\Delta H_{\text {cal }}\right)$ by an integration of the heat capacity curve. Judging from the absence of any transitions upon rescanning the samples, the thermal denaturation of $\beta-\mathrm{HaH}$ was irreversible (Figure 1(a), line C). 


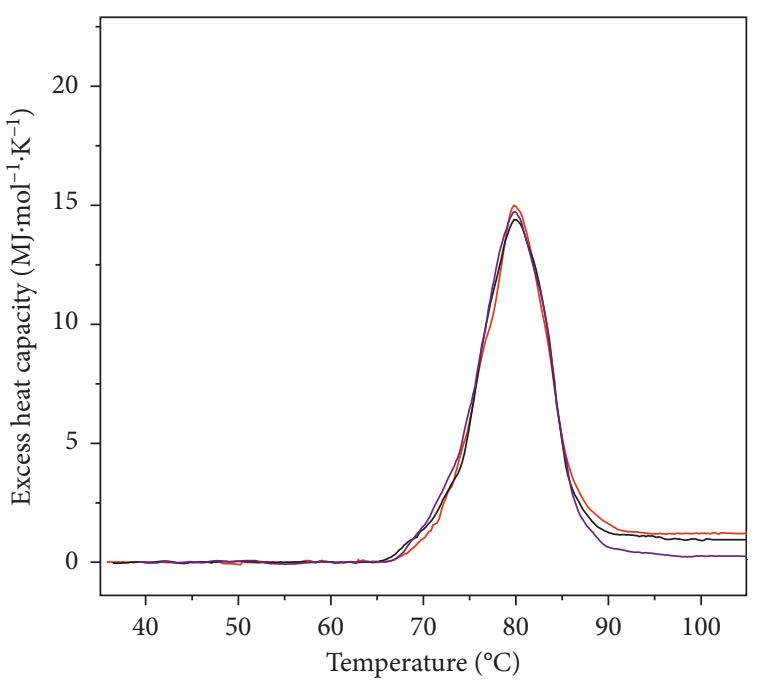

(a)

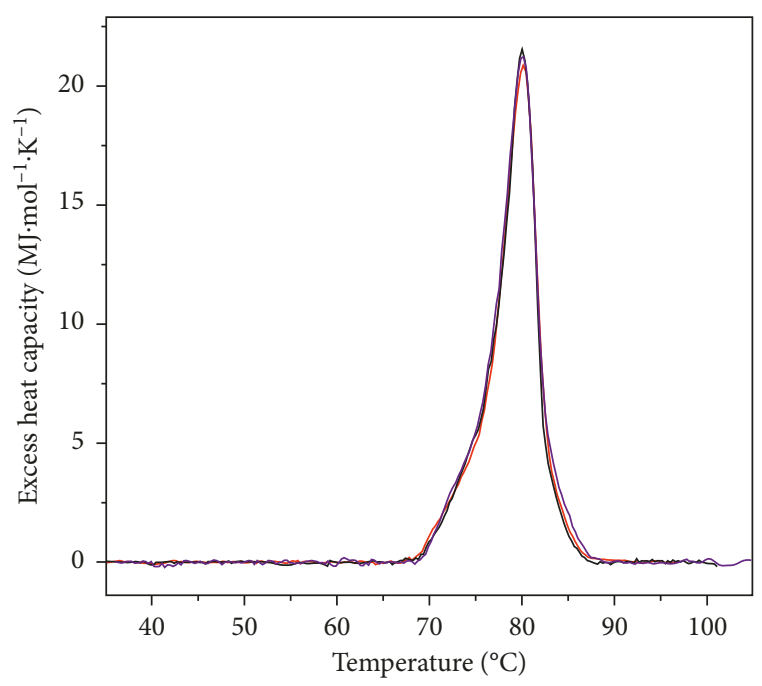

(b)

Figure 3: (a) $C_{p}$ transition curve of $\beta$-HaH in buffer $20 \mathrm{mM}$ HEPES (pH 7.06 at $80^{\circ} \mathrm{C}$ ), recorded at scan rate of $1^{\circ} \mathrm{C}$ min ${ }^{-1}$ and different protein concentrations: $1.01 \mathrm{mg} \cdot \mathrm{ml}^{-1}$ (blue line), $1.91 \mathrm{mg} \cdot \mathrm{ml}^{-1}$ (red line), and $2.88 \mathrm{mg} \cdot \mathrm{ml}^{-1}$ (black line). (b) $C_{p}$ transition curve of $\alpha_{D+N}-\mathrm{HaH}$ in buffer $20 \mathrm{mM} \mathrm{HEPES} \mathrm{(pH} 7.06$ at $80^{\circ} \mathrm{C}$ ), recorded at scan rate of $1^{\circ} \mathrm{C} \mathrm{min}{ }^{-1}$ and different protein concentrations: $2.0 \mathrm{mg} \cdot \mathrm{ml}^{-1}$ (blue line), $3.0 \mathrm{mg} \cdot \mathrm{ml}^{-1}$ (black line), and $4.52 \mathrm{mg} \cdot \mathrm{ml}^{-1}$ (red line).

Analysis of the heating profile of isoform $\alpha_{D+N^{-}} \mathrm{HaH}$, run in the same experimental conditions, revealed asymmetry of the shape, due to two overlapping transitions. In the thermogram of $\alpha_{D+N^{-}} \mathrm{HaH}$, one main transition with an apparent $T_{m}$ of $80^{\circ} \mathrm{C}$ was observed (Figure 1(b), line B). Minor transition at ca. $76^{\circ} \mathrm{C}$ can also be discerned in the thermogram. The thermal denaturation of the Hc isoforms $\alpha_{D+N}-\mathrm{HaH}$ also was found to be irreversible (Figure 1(b), line C). Irreversibility of the thermal denaturation has been observed in DSC measurements of all studied to date Hcs [11-14, 27] and limits the use of a standard equilibrium thermodynamic analysis.

In view of the complex oligomeric Hc structure, the presence of more than one structural domains undergoing thermal unfolding more or less independently of each other is not unexpected. An analysis of DSC contours of the isoform $\alpha_{D+N}-\mathrm{HaH}$ was attempted with a successive annealing procedure, which was shown to be useful for the experimental deconvolution of completely complicated or partially irreversible thermal transitions $[28,29]$. Successive annealing procedure was applied in the analysis of the thermograms of the other studied Hcs [11-13]. Figure 2 shows an example of this procedure, which provides two irreversible transitions. At first, $\alpha_{D+N}-\mathrm{HaH}$ was heated from $35^{\circ} \mathrm{C}$ up to $90^{\circ} \mathrm{C}$ to determine the number and $T_{m}$ of expected transitions (Figure 2(a), line A). After that, a new sample of the same composition was heated slightly above the shoulder, which appeared at $\sim 74^{\circ} \mathrm{C}$ (Figure 2(a), line B) and after cooling to $35^{\circ} \mathrm{C}$ was reheated up to $90^{\circ} \mathrm{C}$ (Figure 2(a), line $\mathrm{D}$ ). To determine the ascending part of the first transition, subtracting of the second scan from the first one was done (Figure 2(a), line C). The descending part of the curve (line C) was obtained by extrapolation (Figure 2(b), dash lines).

3.2. Concentration Dependence of the Temperature of Denaturation. As is mentioned above, the quaternary

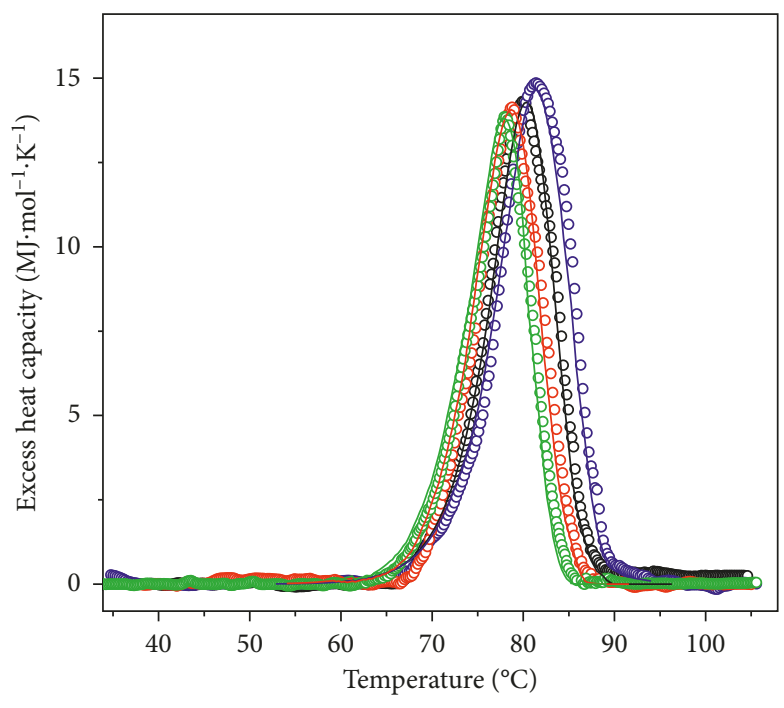

Figure 4: Dependence of the $C_{p}$ transition curves of $\beta$-HaH in buffer $20 \mathrm{mM}$ HEPES ( $\mathrm{pH} 7.06$ at $80^{\circ} \mathrm{C}$ ), with a scan rate: $0.24^{\circ} \mathrm{C} \mathrm{min}{ }^{-1}$, green symbols; $0.5^{\circ} \mathrm{C} \mathrm{min}^{-1}$, red symbols; $1.0^{\circ} \mathrm{C} \mathrm{min}^{-1}$, black symbols; $1.5^{\circ} \mathrm{C} \mathrm{min}^{-1}$, blue symbols. In all cases the protein concentration was $2.88 \mathrm{mg} \cdot \mathrm{ml}^{-1}$. The solid lines represent the theoretical fitting curves based on (3).

structure of the $\mathrm{Hc}$ molecule represents oligomer of twenty subunits (didecamer). Dissociation of the Hc molecule to individual subunits may take place during the denaturation process. According to the equilibrium thermodynamics, any change in the oligomerization state of the protein during the denaturation process should produce a concentration dependence of $T_{m}$. In order to determine whether this was occurring, DSC traces were collected at various protein concentrations, at a constant scan rate of $1^{\circ} \mathrm{C} \mathrm{min}-1$. DSC experiments showed that the $T_{m}$ and calorimetric enthalpy 


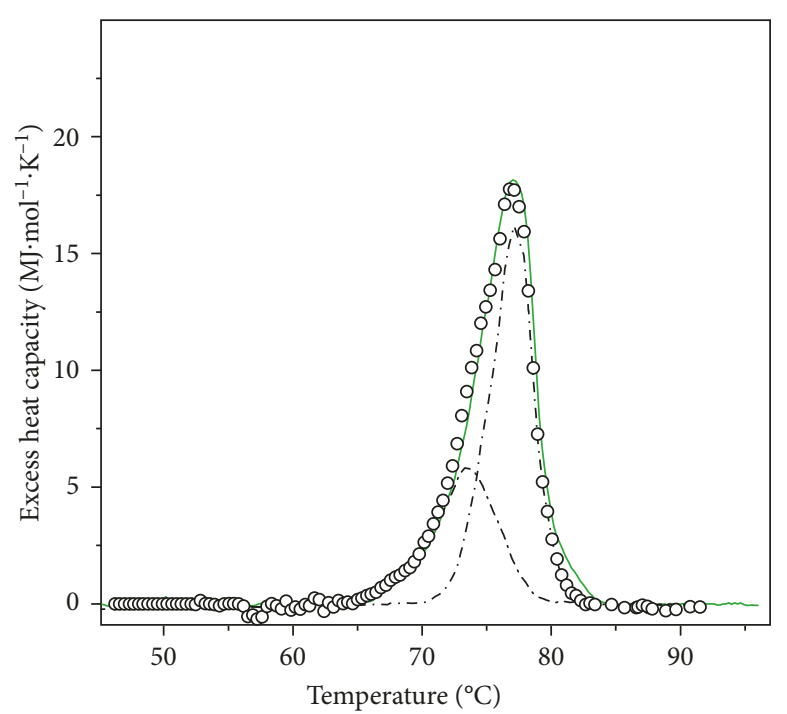

(a)

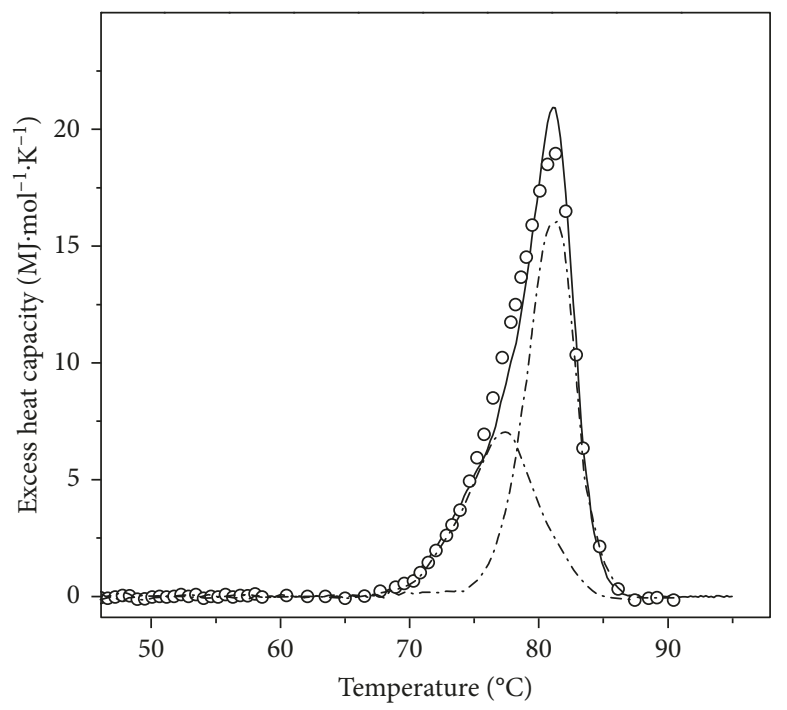

(c)

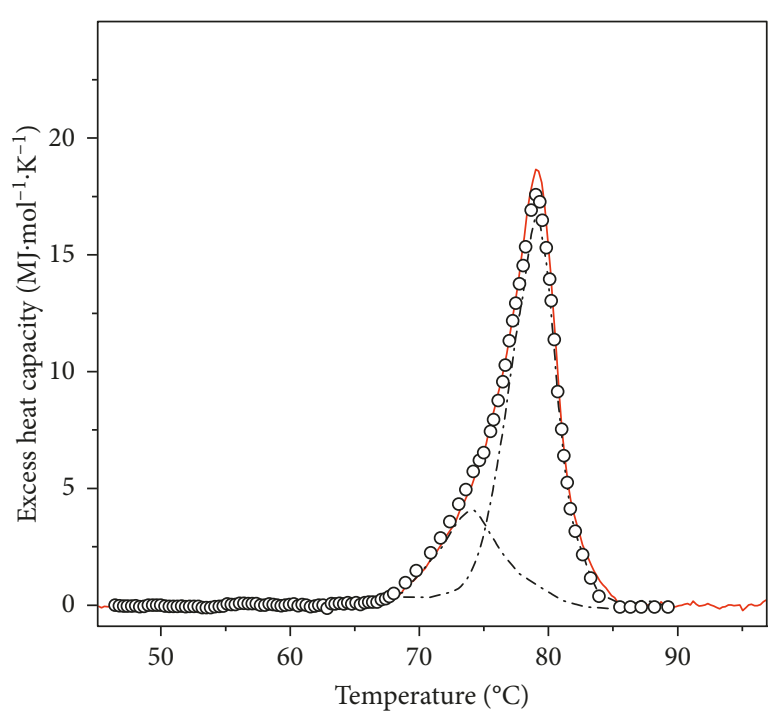

(b)

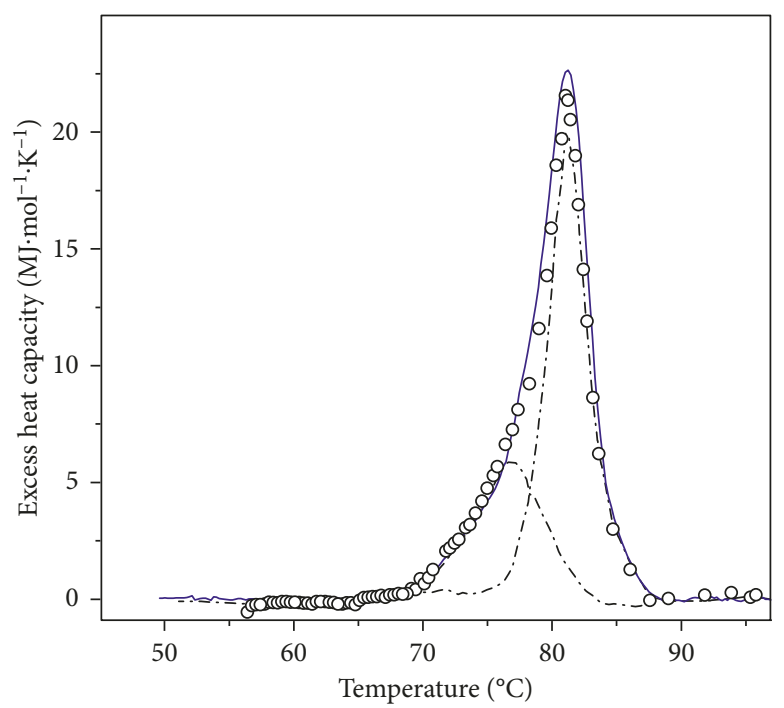

(d)

Figure 5: Dependence of the $C_{p}$ transition curves of $\alpha_{D+N^{-}} \mathrm{HaH}$ isoforms in buffer $20 \mathrm{mM}$ HEPES (pH 7.06 at $80^{\circ} \mathrm{C}$ ), with a scan rate: $0.2^{\circ} \mathrm{C} \mathrm{min}^{-1}$ (a); $0.5^{\circ} \mathrm{C} \mathrm{m^{-1 }}$ (b); $1.0^{\circ} \mathrm{C} \mathrm{min}^{-1}$ (c); $1.5^{\circ} \mathrm{C} \mathrm{min}^{-1}$ (d). Continuous lines depict the experimental data; dash dot lines show the experimental individual components, result of the annealing process, and symbols represent the result of the sum of the corresponded individual components. In all cases, the protein concentration was $3 \mathrm{mg} \cdot \mathrm{ml}^{-1}$.

$\left(\Delta H_{\text {cal }}\right)$ values for the thermal unfolding of isoforms $\beta$ - $\mathrm{HaH}$ and $\alpha_{D+N} \mathrm{HaH}$ were independent of the protein concentration (Figures 3(a) and 3(b)); therefore, denatured proteins remained in the same oligomerization state as the native ones. Consistent with our previous studies, the heat absorption observed in the DSC curves $\left(T_{m} \sim 80^{\circ} \mathrm{C}\right)$ is connected to the melting of the compact $\mathrm{Hc}$ quaternary structure without simultaneous dissociation into subunits [11-13]. This indicates that the interactions between the subunits, constituting the Hc molecules, are strong enough to prevent dissociation before the rate-determining step of the process of thermal unfolding.

3.3. Scan Rate Dependence. In the case of irreversible thermal denaturation of proteins, the calorimetric profiles are scan rate dependent, and the process is under kinetic control. Figure 4 shows the excess heat capacity function versus temperature profiles of the isoform $\beta-\mathrm{HaH}$ at four different scan rates $\left(0.24,0.5,1.0\right.$, and $\left.1.5^{\circ} \mathrm{C} \mathrm{min}^{-1}\right)$. The transition temperature of the irreversible thermal denaturation of $\beta-\mathrm{HaH}$ is scan rate dependent; the maximum of the DSC profiles is shifted toward lower temperatures with a reduction in scan rate (Figure 4).

The transition temperature of $\alpha_{D+N^{-}} \mathrm{HaH}$ isoforms is also scan rate dependent, indicating that the process of thermal unfolding is kinetically controlled (Figures 5(a)-5(d)).

As it is evident from Figures 4 and 5, the DSC traces for both $\mathrm{HaH}$ isoforms were strongly dependent on the scan rate, which prompted us to analyze this nonequilibrium process based on the simplest model of irreversible thermal denaturation of proteins (1). The excess heat capacity functions were analyzed by fitting the data to the two-state 


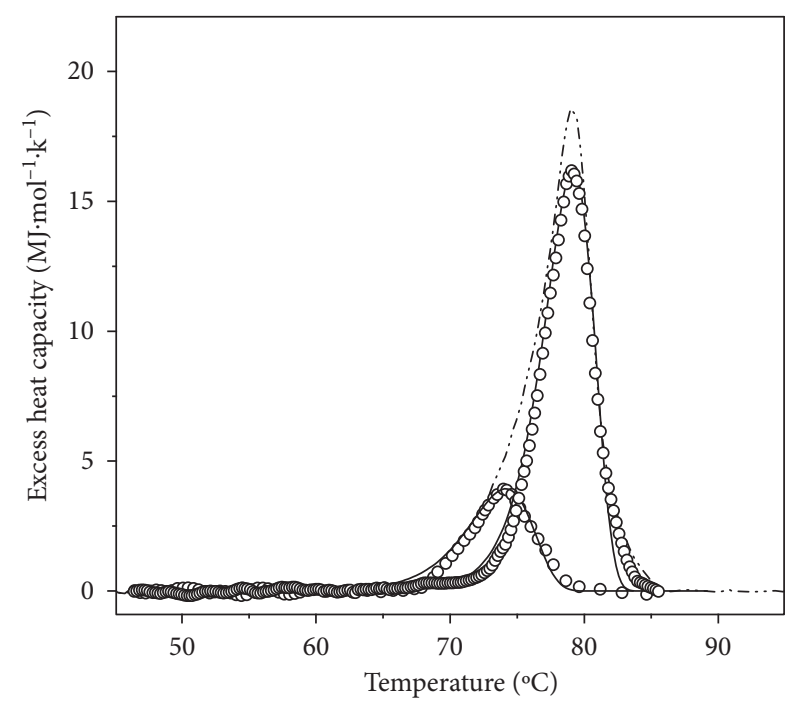

Figure 6: $C_{p}$ transition curve of of $\alpha_{D+N}-\mathrm{HaH}$ isoforms in buffer $20 \mathrm{mM}$ HEPES ( $\mathrm{pH} 7.06$ at $80^{\circ} \mathrm{C}$ ) recorded at scan rate $0.5^{\circ} \mathrm{C} \mathrm{min}{ }^{-1}$. The solid lines represent the theoretical fitting curves based on (3), lines with symbols show the curves obtained from the deconvolution procedure, and the dash dot line represent the experimental $C_{p}$ transition curve.

TABle 1: Arrhenius equation parameters, estimated for the twostate irreversible model of the thermal denaturation of isoform $\beta-\mathrm{HaH}$, at neutral $\mathrm{pH}$.

\begin{tabular}{lcccc}
\hline \multirow{2}{*}{ Parameter } & \multicolumn{4}{c}{ Temperature scan rate $\left({ }^{\circ} \mathrm{C} \mathrm{min}{ }^{-1}\right)$} \\
& 0.24 & 0.5 & 1.0 & 1.5 \\
\hline$T_{m}\left({ }^{\circ} \mathrm{C}\right)$ & 77.90 & 78.80 & 79.88 & 81.40 \\
$\Delta H_{\mathrm{cal}}\left(\mathrm{MJ} \cdot \mathrm{mol}^{-1}\right)$ & 118.6 & 127.4 & 145.0 & 154.0 \\
$E_{a}\left(\mathrm{~kJ} \cdot \mathrm{mol}^{-1}\right)$ & $307 \pm 7$ & $316 \pm 4$ & $302 \pm 6$ & $306 \pm 8$ \\
$T^{*}\left({ }^{\circ} \mathrm{C}\right)$ & $84.6 \pm 0.5$ & $84.8 \pm 0.3$ & $85.0 \pm 0.4$ & $84.9 \pm 0.3$ \\
$r$ & 0.992 & 0.993 & 0.996 & 0.994 \\
\hline
\end{tabular}

irreversible model according to (3) (Figures 4 and 6). Applying this analysis on the observed transitions of the two $\mathrm{HaH}$ isoforms, the kinetic parameters presented in Tables 1 and 2 were obtained.

The thermal denaturation of Hcs from different species has been described by the two-state irreversible model, and the parameters of the Arrhenius equation have been calculated, allowing comparison of transitions during $\mathrm{Hc}$ denaturation $[11-13,26,27]$. The activation energy value of $302.0 \pm 6\left(\mathrm{~kJ} \cdot \mathrm{mol}^{-1}\right)$ and $596.0 \pm 10\left(\mathrm{~kJ} \cdot \mathrm{mol}^{-1}\right)$ was determined for $\beta-\mathrm{HaH}$ and $\alpha_{D+N}-\mathrm{HaH}$, respectively, which is in good agreement with values reported for Hcs in related species (Table 3). The structural organization of these Hcs is similar (didecamer), so it is difficult to propose a structural basis for the difference in their thermal stability. From the other hand, a difference in the carbohydrate content of Hcs has been observed [30]. Hence, a correlation between the thermal stability of Hcs and their carbohydrate content could be expected [31]. Actually, the most thermostable $\beta$-Hc of $H$. pomatia contains 7\% (w/w) carbohydrates [32], while carbohydrate content of $2.6 \%(\mathrm{w} / \mathrm{w})$ has been
TABLE 2: Arrhenius equation parameters, estimated for the twostate irreversible model of the thermal denaturation of isoform $\alpha_{D+N^{-}} \mathrm{HaH}$, at neutral $\mathrm{pH}$.

\begin{tabular}{|c|c|c|c|c|}
\hline \multirow{2}{*}{ Parameter } & \multicolumn{4}{|c|}{ Temperature scan rate $\left({ }^{\circ} \mathrm{C} \min ^{-1}\right)$} \\
\hline & 0.2 & 0.5 & 1.0 & 1.5 \\
\hline \multicolumn{5}{|l|}{ First transition } \\
\hline$T_{m}\left({ }^{\circ} \mathrm{C}\right)$ & 73.4 & 74.0 & 76.4 & 77.0 \\
\hline$\Delta H_{\mathrm{cal}}\left(\mathrm{MJ} \cdot \mathrm{mol}^{-1}\right)$ & 31.10 & 34.07 & 39.10 & 41.27 \\
\hline$E_{a}\left(\mathrm{~kJ} \cdot \mathrm{mol}^{-1}\right)$ & $424 \pm 9$ & $434 \pm 6$ & $418 \pm 5$ & $423 \pm 7$ \\
\hline$T^{*}\left({ }^{\circ} \mathrm{C}\right)$ & $80.8 \pm 0.5$ & $79.0 \pm 0.3$ & $80.0 \pm 0.4$ & $79.0 \pm 0.3$ \\
\hline$r$ & 0.989 & 0.985 & 0.988 & 0.987 \\
\hline \multicolumn{5}{|l|}{ Second transition* } \\
\hline$T_{m}\left({ }^{\circ} \mathrm{C}\right)$ & 77.1 & 79.02 & 80.07 & 81.20 \\
\hline$\Delta H_{\mathrm{cal}}\left(\mathrm{MJ} \cdot \mathrm{mol}^{-1}\right)$ & 69.9 & 79.0 & 79.8 & 81.4 \\
\hline$E_{a}\left(\mathrm{~kJ} \cdot \mathrm{mol}^{-1}\right)$ & $586 \pm 12$ & $564 \pm 8$ & $596 \pm 10$ & $601 \pm 14$ \\
\hline$T^{*}\left({ }^{\circ} \mathrm{C}\right)$ & 83.8 & 83.9 & 83.7 & 83.6 \\
\hline$r$ & 0.995 & 0.996 & 0.993 & 0.994 \\
\hline
\end{tabular}

${ }^{*}$ Main transition.

TABle 3: Parameters for the thermal denaturation of $\mathrm{HaH}$ isoforms obtained by DSC at scan rate of $1^{\circ} \mathrm{C} \mathrm{min}^{-1}$. Comparison with data obtained for Hcs of R. thomasiana [11], H. pomatia [12], C. concholepas [13], and H. rubra [27].

\begin{tabular}{lccc}
\hline Hemocyanin & $T_{\mathrm{m}}{ }^{*}\left({ }^{\circ} \mathrm{C}\right)$ & $\begin{array}{c}\Delta \mathrm{Hcal}^{-1} \\
\left(\mathrm{MJ} \cdot \mathrm{mol}^{-1}\right)\end{array}$ & $E_{a}\left(\mathrm{~kJ} \cdot \mathrm{mol}^{-1}\right)$ \\
\hline H. aspersa $\beta-\mathrm{Hc}(\beta-\mathrm{HaH})$ & 79.88 & $145 \pm 1.0$ & $302.0 \pm 6$ \\
$\begin{array}{l}\text { H. aspersa } \alpha_{D+N}-\mathrm{Hc} \\
\left(\alpha_{\left.D+N^{-H a H}\right)}\right.\end{array}$ & 80.07 & $79.8 \pm 1.0$ & $596.0 \pm 10$ \\
R. thomasiana $\mathrm{Hc}(\mathrm{RtH})$ & 82.4 & $195 \pm 1.0$ & $597.0 \pm 20$ \\
H. pomatia $\beta-\mathrm{Hc}(\beta-\mathrm{HpH})$ & 84.0 & $190 \pm 1.0$ & $521.0 \pm 7$ \\
C. concholepas $\mathrm{Hc}(\mathrm{CCH})$ & 78.0 & $120 \pm 1.0$ & $323.0 \pm 2$ \\
H. rubra $\mathrm{Hc}$ & 78.9 & - & $535.0 \pm 65$ \\
\hline
\end{tabular}

*Main transition.

determined for RtH [30]. Data about the carbohydrate content of the Hcs of gastropods C. concholepas and $H$. aspersa maxima, however, are still not available in the literature.

The present study confirms that the two-state irreversible model, built especially on experimental examinations on small globular proteins will hold true for larger oligomeric proteins as well [33]. Nevertheless, as Lyubarev and Kurganov noted in [34], that experimental data are satisfactorily described by the two-state model, the real mechanism of protein denaturation can be more complex. Therefore, it should be stressed that the obtained values for the activation energy of the denaturation process are apparent and characterize the initial rate-limiting step of the process.

\section{Conclusions}

The results of the present study on the isoforms of the $\mathrm{Hc}$, isolated from snails Helix aspersa maxima, allow classifying these $\mathrm{Hcs}$ as thermostable proteins $\left(T_{m} \sim 80^{\circ} \mathrm{C}\right)$. The high degree of oligomerization of hemocyanin molecules, in 
general, is probably one of the reasons for their increased thermal stability. The data obtained will facilitate the further investigation of therapeutic properties and applications of these dioxygen-binding proteins.

\section{Abbreviations}

$\mathrm{HaH}: \quad$ Hemocyanin of Helix aspersa maxima

DSC: Differential scanning calorimetry

Tris-HCl: Tris(hydroxymethyl)aminomethane hydrochloride

HEPES: 4-(2-Hydroxyethyl)-1-piperazineethanesulfonic acid.

\section{Conflicts of Interest}

The authors declare that there are no conflicts of interest regarding the publication of this paper.

\section{References}

[1] T. Morrow and L. H. Felcone, "Defining the difference: what makes biologics unique," Biotechnology Healthcare, vol. 1, no. 4, pp. 24-26, 2004.

[2] A. Buchanan, F. Ferraro, S. Rust et al., "Improved drug-like properties of therapeutic proteins by directed evolution," Protein Engineering, Design and Selection, vol. 25, pp. 631-638, 2012.

[3] S. Krumova, S. Todinova, M. Tileva et al., "Thermal stability and binding energetics of thymidylate synthase ThyX," International Journal of Biological Macromolecules, vol. 91, pp. 560-567, 2016.

[4] K. Huus, S. Havelund, H. B. Olsen, M. van de Weert, and S. Frokjaer, "Chemical and thermal stability of insulin: effects of zinc and ligand binding to the insulin zinc-hexamer," Pharmaceutical Research, vol. 23, pp. 2611-2620, 2006.

[5] S. Todinova, M. Guncheva, and D. Yancheva, "Thermal and conformational stability of insulin in the presence of imidazolium-based ionic liquids," Journal of Thermal Analysis and Calorimetry, vol. 123, pp. 2591-2598, 2016.

[6] G. Préaux and C. Gielens, "Hemocyanins," in Copper Proteins and Copper Enzymes, R. Lontie, Ed., vol. 2pp. 159-205, CRC Press, Boca Raton, FL, USA, 1984.

[7] K. E. van Holde and K. I. Miller, "Hemocyanins," Advance in Protein Chemistry, vol. 47, pp. 1-81, 1995.

[8] A. Tchorbanov, K. Idakieva, N. Mihaylova, and L. Doumanova, "Modulation of the immune response using Rapana thomasiana hemocyanin," International Immunopharmacology, vol. 8, pp. 1033-1038, 2008.

[9] V. Gesheva, K. Idakieva, N. Kerekov et al., "Marine gastropod hemocyanins as adjuvants of non-conjugated bacterial and viral proteins," Fish and Shellfish Immunology, vol. 30, no. 1, pp. 135-142, 2011.

[10] V. Gesheva, S. Chausheva, N. Mihaylova et al., "Anti-cancer properties of gastropodan hemocyanins in murine model of colon carcinoma," BMC Immunology, vol. 15, no. 1, pp. 34-44, 2014.

[11] K. Idakieva, K. Parvanova, and S. Todinova, "Differential scanning calorimetry of the irreversible denaturation of Rapana thomasiana (marine snail, Gastropod) hemocyanin," Biochimica et Biophysica Acta, vol. 1748, no. 1, pp. 50-56, 2005.
[12] K. Idakieva, C. Gielens, N. I. Siddiqui et al., "Irreversible thermal denaturation of $\beta$-hemocyanin of Helix pomatia and its substructures studied by differential scanning Calorimetry," Zeitschrift für Naturforschung A, vol. 62, no. 9, pp. 499-506, 2007.

[13] K. Idakieva, P. Nikolov, I. Chakarska, V. L. Shnyrov, and N. Genov, "Spectroscopic properties and conformational stability of Concholepas concholepas hemocyanin," Journal of Fluorescence, vol. 18, no. 3-4, pp. 715-725, 2008.

[14] R. Sterner, T. Vogl, H. J. Hinz et al., "Extreme thermostability of tarantula hemocyanin," FEBS Letters, vol. 364, no. 1, pp. 9-12, 1995.

[15] K. Idakieva, Y. Raynova, F. Meersman, and C. Gielens, "Phenoloxidase activity and thermostability of Cancer pagurus and Limulus polyphemus hemocyanin," Comparative Biochemistry and Physiology, vol. 164, no. 3, pp. 201-209, 2013.

[16] K. Idakieva, F. Meersman, and C. Gielens, "Reversible heat inactivation of copper sites precedes thermal unfolding of molluscan (Rapanathomasiana) hemocyanin," Biochimica et Biophysica Acta, vol. 1824, no. 5, pp. 731-738, 2012.

[17] B. Lieb and J. Markl, "Evolution of molluscan hemocyanins as deduced from DNASequencing," Micron, vol. 35, no. 1-2, pp. 117-119, 2004.

[18] K. Streit, D. Jackson, B. M. Degnan, and B. Lieb, "Developmental expression of two Haliotis asinina hemocyanin isoforms," Differentiation, vol. 73, no. 7, pp. 341-349, 2005.

[19] K. Heirwegh, H. Borginon, and R. Lontie, "Separation and absorption spectra of $\alpha$ - and $\beta$-hemocyanin of Helix pomatia," Biochimica et Biophysica Acta, vol. 48, no. 3, pp. 517-526, 1961.

[20] R. Lontie, "Components, functional units, and active sites of Helix pomatia hemocyanin," Life Chemistry Reports, no. 1, pp. 109-120, 1983.

[21] C. Gielens, J. De Sadeleer, G. Preaux, and R. Lontie, "Identification, separation and cheracterization of the hemocyanin components of Helix aspersa," Comparative Biochemistry and Physiology Part B: Comparative Biochemistry, vol. 88, pp. 181-186, 1987.

[22] L. Velkova, I. Dimitrov, H. Schwarz et al., "Structure of hemocyanin from garden snail Helix lucorum," Comparative Biochemistry and Physiology Part B: Biochemistry and Molecular Biology, vol. 157, no. 1, pp. 16-26, 2010.

[23] Y. Raynova, L. Doumanova, and K. Idakieva, "Phenoloxidase activity of Helix aspersa maxima (garden snail, Gastropod) hemocyanin," Protein Journal, vol. 32, no. 8, pp. 609-618, 2013.

[24] Y. Raynova, S. Todinova, D. Yordanov, and K. Idakieva, "SDSinduced phenoloxidase activity of Helix aspersa maxima hemocyanin," Bulgarian Chemical Communications, vol. 46, pp. 111-116, 2014.

[25] R. Lumry and H. Eyring, "Conformational changes in proteins," Journal of Physical Chemistry, vol. 58, no. 2, pp. 110-120, 1954.

[26] B. I. Kurganov, A. E. Lyubarev, J. M. Sanchez-Ruiz, and V. L. Shnyrov, "Analysis of differential scanning calorimetry data for proteins, criteria of validity of one-step mechanism of irreversible protein denaturation," Biophysical Chemistry, vol. 69, no. 2-3, pp. 125-135, 1997.

[27] G. Marshall, P. Valtchev, F. Dehghani, and G. W. Gomes, "Thermal denaturation and protein stability analysis of Haliotis rubra hemocyanin," Journal of Thermal Analysis and Calorimetry, vol. 123, no. 3, pp. 2499-2505, 2016.

[28] V. Shnyrov, G. Zhadan, and I. Akoev, "Calorimetric measurements of the effect of $330-\mathrm{MHz}$ radiofrequency radiation on human erythrocyte ghosts," Bioelectromagnetics, vol. 5, no. 4, pp. 411-418, 1984. 
[29] V. Shnyrov and P. Mateo, "Thermal transitions in the purple membrane from Halobacterium halobium," FEBS Letters, vol. 324, no. 2, pp. 237-240, 1993.

[30] K. Idakieva, S. Stoeva, W. Voelter, and C. Gielens, "Glycosylation of Rapana thomasiana Hemocyanin. Comparison with Other Prosobranch (Gastropod) Hemocyanins," Comparative Biochemistry and Physiology Part B: Biochemistry and Molecular Biology, vol. 138, no. 3, pp. 221-228, 2004.

[31] C. Wang, M. Eufemi, C. Turano, and A. Giartosio, "Influence of the carbohydrate moiety on the stability of glycoproteins," Biochemistry, vol. 35, no. 23, pp. 7299-7307, 1996.

[32] E. J. Wood, M. F. Chaplin, C. Gielens, J. De Sadeleer, G. Preaux, and R. Lontie, "Relative molecular mass of the polypeptide chain of $\beta$-haemocyanin of Helix pomatia and carbohydrate composition of the functional units," Comparative Biochemistry and Physiology Part B: Comparative Biochemistry, vol. 82, no. 1, pp. 179-186, 1985.

[33] A. E. Lyubarev and B. I. Kurganov, "Study of irreversible thermal denaturation of proteins by differential scanning Calorimetry," Recent Research Developments in Biophysical Chemistry, vol. 2, pp. 141-165, 2001.

[34] A. E. Lyubarev and B. I. Kurganov, "Analysis of DSC data relating to proteins undergoing irreversible thermal denaturation," Journal of Thermal Analysis and Calorimetry, vol. 62, no. 1, pp. 51-62, 2000. 

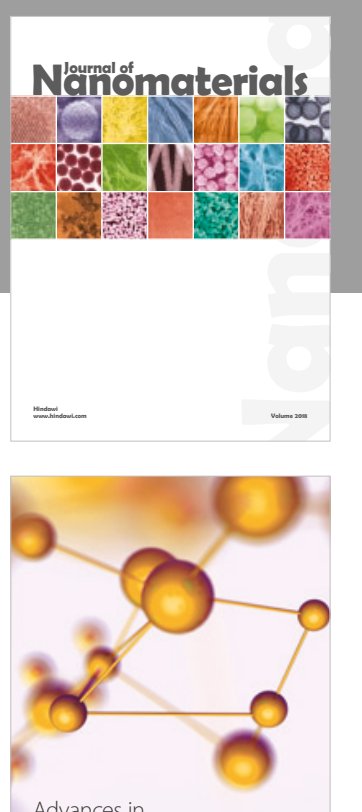

Physical Chemistry
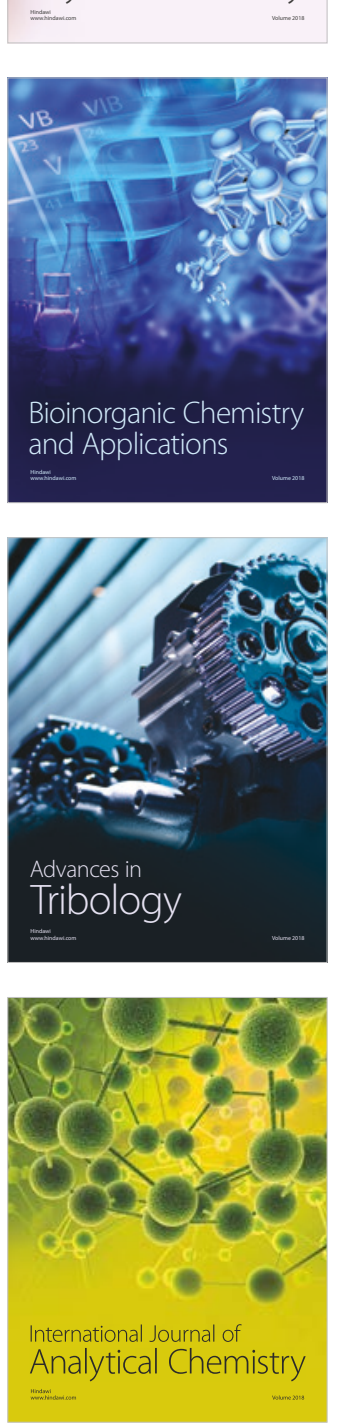

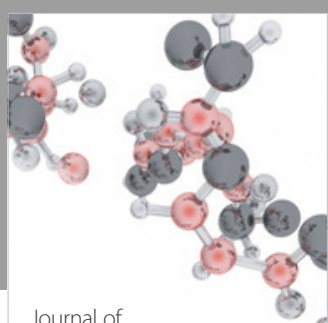

Analytical Methods

in Chemistry

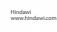

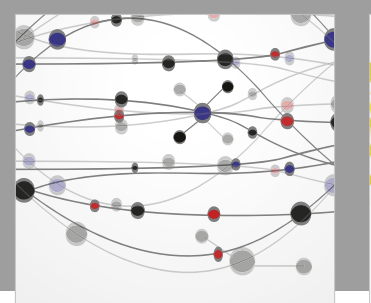

The Scientific World Journal

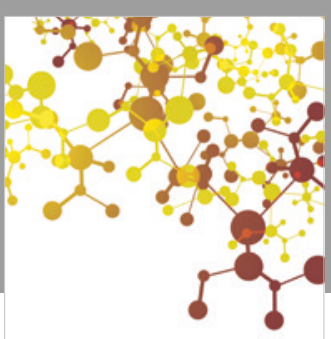

Journal of

Applied Chemistry
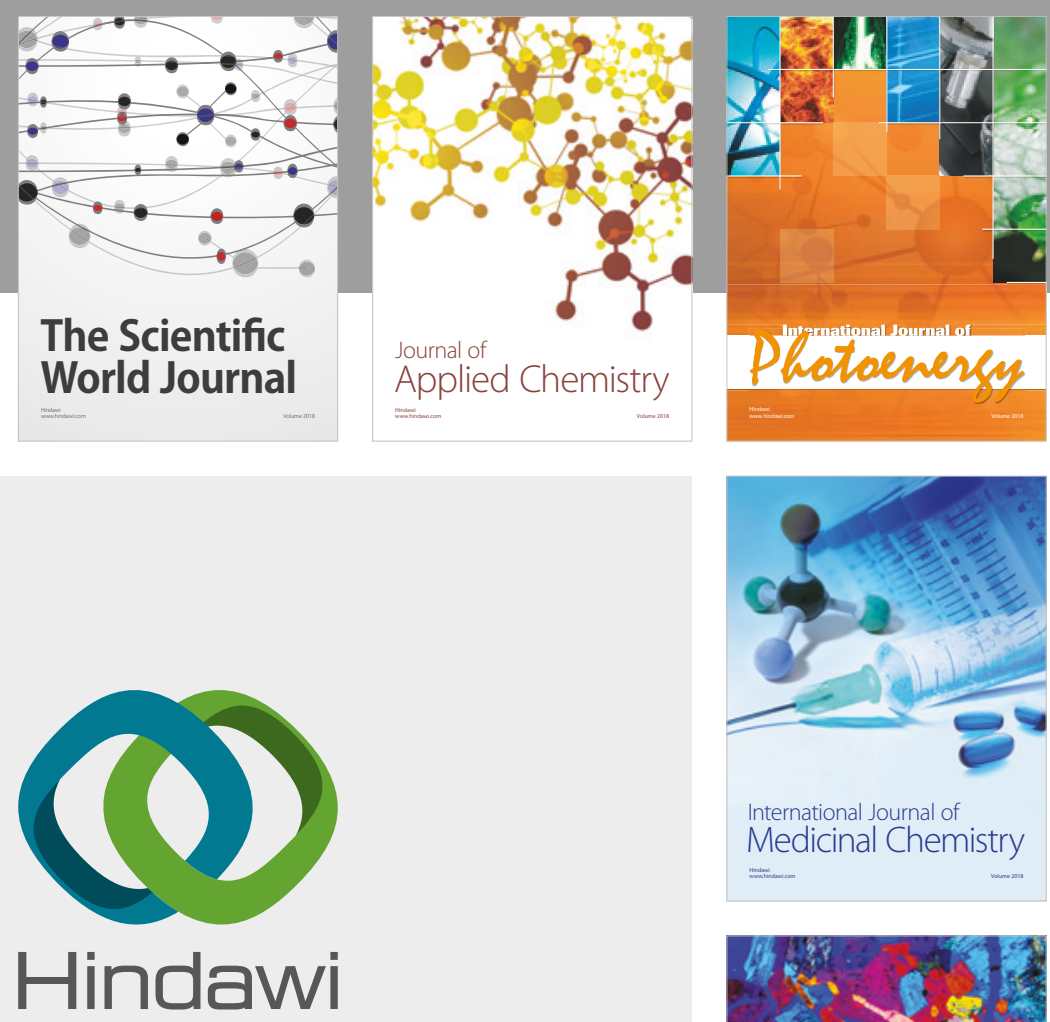

Submit your manuscripts at

www.hindawi.com
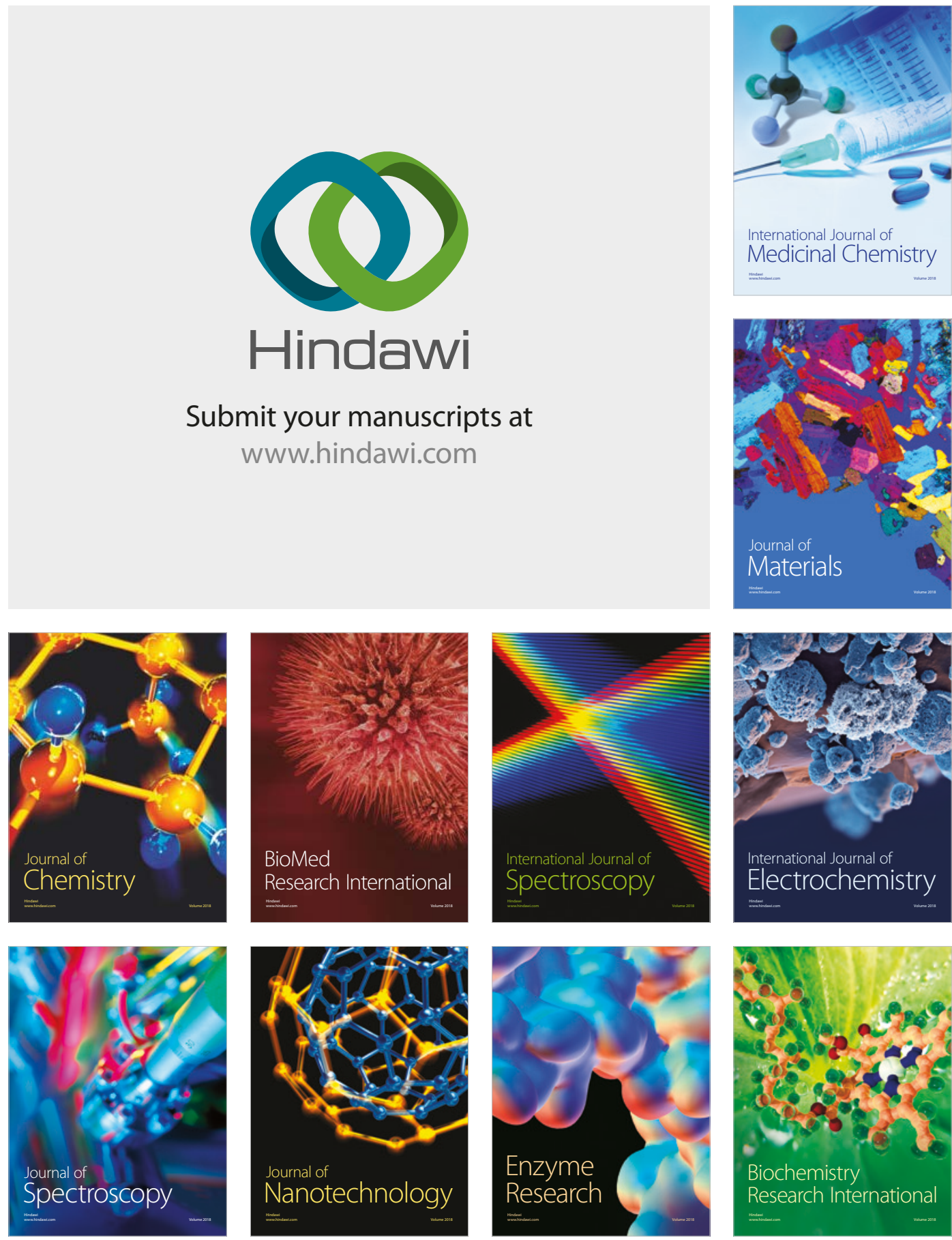
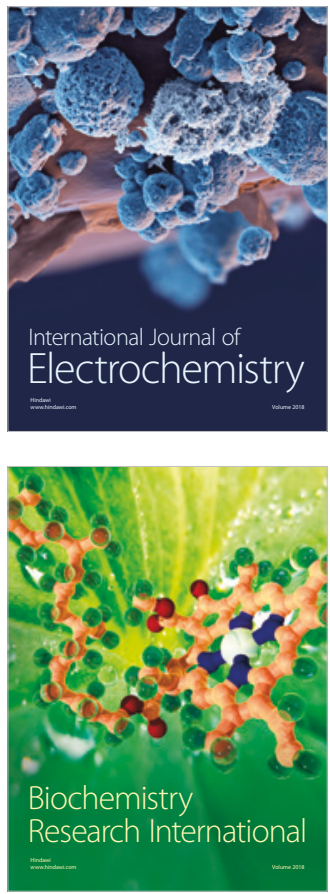